\title{
Transfer of Arthrobacter picolinophilus Tate and Ensign 1974 to Rhodococcus erythropolis
}

\author{
CATHRIN KOCH, STEFAN KLATTE, PETER SCHUMANN, JUTTA BURGHARDT, \\ REINER M. KROPPENSTEDT, AND ERKO STACKEBRANDT* \\ DSM-Deutsche Sammlung von Mikroorganismen und Zellkulturen GmbH, D-38124 Braunschweig, Germany
}

\begin{abstract}
The type strain of Arthrobacter picolinophilus, strain DSM 20665 (= ATCC 27854), was found to be so closely related to strains of Rhodococcus erythropolis that we propose that this misclassified taxon should be removed from the genus Arthrobacter and reclassified as a strain of $R$. erythropolis. Our conclusion is based on the results of a comparative analysis of the chemotaxonomic properties of the organism, including the amino acid composition of the peptidoglycan, the mycolic acid composition, and the fatty acid composition, the very similar physiological properties and $16 \mathrm{~S}$ ribosomal DNA sequences, and the results of DNA-DNA reassociation experiments performed by the renaturation rate method.
\end{abstract}

Arthrobacter picolinophilus was described on the basis of a strain which resembled Arthrobacter species morphologically and in which branching was not observed (19). The ability to utilize picolinate as a sole carbon and energy source in a mineral salts medium when the organism was provided with L-methionine and thiamine was the most salient feature. This species was included on the Approved Lists of Bacterial Names (17). Shortly after the name became valid, a mycolic acid with a chain length of 32 to 34 carbon atoms was reported to be present in this organism, which indicated that this species should not be considered a genuine member of the genus Arthrobacter but is a member of the genus Rhodococcus $(2,6)$. Thus, $A$. picolinophilus was considered a species incertae sedis, but formal transfer to the genus Rhodococcus has not formally proposed previously (6).

Assignment of $A$. picolinophilus DSM $20665^{\mathrm{T}}$ ( $\mathrm{T}=$ type strain) to the species Rhodococcus erythropolis is strongly supported by the presence of identical amino acids in the peptidoglycan and identical isoprenoid quinones and by the presence of mycolic acids in the two taxa. The peptide subunits of the peptidoglycan are directly cross-linked; the diagnostic amino acid of the peptidoglycan is meso-diaminopimelic acid (Al $\gamma$ peptidoglycan type according to Schleifer and Kandler [16]), and the glycan moiety of the cell walls contains $N$-glycolyl residues ( $N$-glycolyl muramic acid) (20).

The whole-cell sugar pattern is a type A pattern (12); the whole-cell sugars include an arabinogalactan and no xylose. The prominent menaquinone is $\mathrm{MK}-8\left(\mathrm{H}_{2}\right)$, determined as described previously (11). The G+C content of the DNA of $A$. picolinopilus is 65.2 mol\% (19), which is within the ranges reported for Rhodococcus species (60 to $69 \mathrm{~mol} \%$ [2]) and Arthrobacter species (59 to $66 \mathrm{~mol} \%$ [6]).

In the course of a phylogenetic analysis of the genus $\mathrm{Ar}$ throbacter $(9,10)$, a comparative $16 \mathrm{~S}$ ribosomal DNA analysis (15) indicated that $A$. picolinophilus DSM $20665^{\mathbf{T}}$ did not cluster with members of the genus Arthrobacter, but was highly related to Rhodococcus species. The highest $16 \mathrm{~S}$ ribosomal DNA similarity values found were the values between $A$. picolinophilus and two strains of $R$. erythropolis, type strain DSM

\footnotetext{
* Corresponding author. Mailing address: DSM-Deutsche Sammlung von Mikroorganismen und Zellkulturen $\mathrm{GmbH}$, Mascheroder Weg 1B, D-38124 Braunschweig, Germany. Phone: 49-5312616-352. Fax: 49-531-2616-418. Electronic mail address: stackebrandt @venus.gbf-braunschweig.d400.de.
}

43066 (99.4\% similarity) and strain DSM 43188 (formerly classified as the type strain of Nocardia calcarea [14] (99.7\% similarity). As even a very high binary $16 \mathrm{~S}$ ribosomal DNA similarity value does not eliminate the possibility that there are two species (18), DNA similarity studies were performed with $A$. picolinophilus and $R$. erythropolis DSM $43066^{\mathrm{T}}$ and DSM 43188 by using the renaturation rate method $(1,3,4)$; while the similarity value found for the two $R$. erythropolis strains was $99.0 \%$, the values obtained for the Arthrobacter strain and the two Rhodococcus strains were 72 and $75 \%$, respectively. These values are higher than the DNA similarity threshold value recommended for species delineation (70\%) (21).

Transfer of $A$. picolinophilus to $R$. erythropolis is also justified by the very similar mycolic acid and fatty acid compositions and very similar physiological reactions of these organisms. An analysis of the mycolic acids (8) (Table 1 ) revealed that strain DSM $20665^{\mathrm{T}}$ could be identified as an $R$. erythropolis strain with a high score (similarity index, 0.778 ) by using the Microbial Identification System (MIDI, Newark, Del.) modified for mycolic acids (8). Similarly, an analysis of the fatty acids of these strains $(11,13)$ (Table 2) gave a high score for strain DSM $20665^{T}$ and $R$. erythropolis (similarity index, 0.835 ) with the Microbial Identification System when the modified database of Klatte et al. was used (8). A numerical analysis of the mycolic acid and fatty acid compositions of Rhodococcus species and a determination of the levels of similarity based on Euclidian distances revealed that species of this genus can be separated from each other by distances ranging from 24 to 30 for mycolic acids and from 12 to 15 for fatty acids (7). In both kinds of analyses $A$. picolinophilus and strains of $R$. erythropolis formed a single coherent cluster within the branching pattern of Rhodococcus species (7).

An analysis of physiological properties in which we tested the ability of DSM $20665^{\mathrm{T}}$ and 13 strains of $R$. enthropolis to metabolize 35 compounds by the system of Kämpfer et al. (5) as modified by Klatte et al. (9) resulted in a Willcox probability value of $100 \%$. The following tests were found to be positive for all strains of $R$. erythropolis and strain DSM $20665^{\mathrm{T}}$ : utilization of gluconate, myo-inositol, citrate, succinate, L-alanine, $\mathrm{L}$-valine, putrescine, quinate, para-nitrophenol- $\beta$-D-xyloside, para-nitrophenol-phosphoryl-choline, and 2-deoxythymidine5-para-nitrophenol-phosphate. Between 7 and 12 of the 13 strains of $R$. erythropolis exhibited the same reactions as strain DSM $20665^{\mathbf{T}}$ in tests to determine the use of D-galactose, D-ribose, saccharose, caprate, D-arabitol, 2-hydroxyvalerate, 4-aminobutyrate, L-leucine, acetamide, 4-hydroxybenzoate, 
TABLE 1. Qualitative and quantitative distribution of mycolic acids in $R$. erythropolis DSM $43066^{\mathrm{T}}$ and $A$. picolinophilus DSM $20665^{\mathrm{T}}$

\begin{tabular}{lrc}
\hline \multirow{2}{*}{ Mycolic acid } & \multicolumn{2}{c}{$\%$ of total mycolic acids in: } \\
\cline { 2 - 3 } & DSM $43066^{\mathrm{T}}$ & DSM $2065^{\mathrm{T}}$ \\
\hline $30: 0^{a}$ & & 3 \\
$31: 0$ & 4 & 5 \\
$32: 0$ & 3 & 3 \\
$33: 0$ & 12 & 12 \\
$34: 0$ & 4 & 6 \\
$35: 0$ & 2 & 2 \\
36 unsaturated $\mathrm{a}^{b}$ & 7 & 6 \\
36 unsaturated $\mathrm{b}^{b}$ & 10 & 11 \\
$36: 0$ & 4 & 5 \\
37 unsaturated & 3 & 4 \\
$37: 0$ & 12 & 11 \\
38 unsaturated & 3 & 4 \\
$38: 0$ & 6 & 5 \\
$39: 0$ & 11 & 11 \\
$40: 0$ & 4 & 4 \\
$41: 0$ & 2 & 4 \\
42 unsaturated & 5 & 1 \\
$42: 0$ & 1 & 1 \\
$43: 0$ & 1 & 1 \\
44 unsaturated & 2 & \\
$44: 0$ & & \\
\hline & & \\
\hline
\end{tabular}

${ }^{a}$ Number of carbon atoms:number of double bonds.

${ }^{b}$ Unsaturated mycolic acid in which the position and degree of unsaturation are not known.

and phenylacetate, and these strains were not able to use D-glucosamine, L-rhamnose, D-furanose, pimelate, L-aspartate, and 3-hydroxybenzoate. Strain DSM $20665^{\mathrm{T}}$ did not metabolize $N$-acetyl-D-glucosamine and 2-oxoglutarate, while the ma-

TABLE 2. Qualitative and quantitative distribution of fatty acids in strains of $R$. erythropolis and $A$. picolinophilus DSM $20665^{\mathrm{T}}$

\begin{tabular}{lcc}
\hline \multirow{2}{*}{ Fatty acid } & \multicolumn{2}{c}{ \% of total fatty acids in: } \\
\cline { 2 - 3 } & R. erythropolis strains ${ }^{a}$ & DSM $20665^{\mathrm{T}}$ \\
\hline Unknown $^{b}$ & 0.53 & 0.55 \\
$14: 0$ & 6.11 & 5.85 \\
$15: 1$ cis-9 & 1.07 & 0.63 \\
$15: 0$ & 4.71 & 3.87 \\
$16: 1$ cis-7 & 1.95 & 2.86 \\
$16: 1$ cis-9 & 14.53 & 14.87 \\
$16: 0$ & 24.53 & 25.03 \\
$17: 1$ cis-9 & 3.45 & 3.30 \\
$17: 1$ cis-11 & 2.85 & 2.11 \\
$17: 0$ & 1.61 & 1.28 \\
$17: 010-$-methyl & 3.56 & 2.65 \\
$18: 0$ cis-9 & 9.69 & 14.24 \\
$18: 0$ & 0.43 & 0.67 \\
$18: 0$ 10-methyl & 17.47 & 16.39 \\
Unknown $^{c}$ & 0.82 & 0.85 \\
\hline
\end{tabular}

${ }^{a}$ Mean values for the fatty acids of type strain DSM 43066 and 11 reference strains (DSM 43060, DSM 43135, DSM 43188, DSM 43200, DSM 43296, DSM 43297, DSM 43440, DSM 43441, DSM 43955, DSM 43957, and DSM 43987).

${ }^{b}$ Fatty acid of unknown structure having an equivalent chain length of 13.961.

${ }^{c}$ Fatty acid of unknown structure having an equivalent chain length of 19.743 jority of $R$. erythropolis strains were positive for these characteristics (10 and 9 strains, respectively); four strains of $R$. erythropolis and strain DSM $20665^{\mathrm{T}}$ utilized benzoate.

\section{REFERENCES}

1. De Ley, J., H. Cattoir, and A. Reynaerts. 1970. The quantitative measurement of DNA hybridisation from renaturation rates. Eur. J. Biochem. 12: 133-142.

2. Goodfellow, M. 1986. Genus Rhodococcus, p. 1472-1481. In P. H. A. Sneath, N. S. Mair, M. E. Sharpe, and J. G. Holt (ed.), Bergey's manual of systematic bacteriology, vol. 2. Williams and Wilkins, Baltimore.

3. Huss, V. A. R., H. Festl, and K. H. Schleifer. 1983. Studies on the spectrophotometric determination of DNA hybridization from renaturation rates. Syst. Appl. Microbiol. 4:184-192.

4. Jahnke, K.-D. 1992. BASIC computer program for evaluation of spectroscopic DNA renaturation data from GILFORD SYSTEM 2600 spectrophotometer on a PC/XT/AT type personal computer. J. Microbiol. Methods 15:61-73.

5. Kämpfer, P., W. Dott, and R. M. Kroppenstedt. 1990. Numerical classification and identification of some nocardioform bacteria. J. Gen. Appl. Microbiol. 36:309-391.

6. Keddie, R. M., M. D. Collins, and D. Jones. 1986. Arthrobacter Conn and Dimmick 1947, 300 AL, p. 1288-1301. In P. H. A. Sneath, N. S. Mair, M. E. Sharpe, and J. G. Holt (ed.), Bergey's manual of systematic bacteriology, vol. 2. Williams and Wilkins, Baltimore.

7. Klatte, S. 1994. Polyphasische automatisierte Identifizierung der Gattungen Conynebacterium Lehmann und Neumann 1896 und Rhodococcus Zopf 1891. Ph.D. thesis. University of Osnabrück, Germany.

8. Klatte, S., F. A. Rainey, and R. M. Kroppenstedt. 1994. Transfer of Rhodococcus aichiensis Tsukamura 1982 and Nocardia amarae Lechevalier and Lechevalier 1974 to the genus Gordona as Gordona aichiensis comb. nov. and Gordona amarae comb. nov. Int. J. Syst. Bacteriol. 44:769-773.

9. Koch, C., F. A. Rainey, and E. Stackebrandt. 1994. 16S rDNA studies on members of Arthrobacter and Micrococcus: an aid for their future taxonomic restructuring. FEMS Microbiol. Lett. 123:167-172.

10. Koch, C., and E. Stackebrandt. Reclassification of Micrococcus agilis AliCohen 1889 as Arthrobacter agilis comb. nov. Int. J. Syst. Bacteriol., in press.

11. Kroppenstedt, R. M. 1985 . Fatty acid and menaquinone analysis of actinomycetes and related organisms, p. 173-199. In M. Goodfellow and D. E. Minnikin (ed.), Chemical methods in bacterial systematics. Academic Press, London.

12. Lechevalier, M. P., and H. Lechevalier. 1970. Chemical composition as a criterion in the classification of aerobic actinomycetes. Int. J. Syst. Bacteriol. 20:435-444.

13. Miller, L., and T. Berger. 1985. Bacterial identification by gas chromatography of whole cell fatty acids. Gas chromatography. Applications note 228-41. Hewlett-Packard Co., Avondale, $\mathrm{Pa}$.

14. Rainey, F. A., J. Burghardt, R. M. Kroppenstedt, S. Klatte, and E. Stackebrandt. 1995. Polyphasic evidence for the transfer of Rhodococcus roseus to Rhodococcus rhodochrous. Int. J. Syst. Bacteriol. 45:101-103.

15. Rainey, F. A. M. Dorsch, H. W. Morgan, and E. Stackebrandt. 1992, 16S rDNA analysis of Spirochaeta thermophila: its phylogenetic position and implications for the systematics of the order Spirochaetales. Syst. Appl. Microbiol. 15:197-202.

16. Schleifer, K. H., and O. Kandler. 1972. Peptidoglycan types of bacterial cell walls and their taxonomic implications. Bacteriol. Rev. 36:407-477.

17. Skerman, V. B. D., V. McGowan, and P. H. A. Sneath (ed.). 1980. Approved lists of bacterial names. Int. J. Syst. Bacteriol. 30:225-420.

18. Stackebrandt, E., and B. M. Goebel. 1994. Taxonomic note: a place for DNA-DNA reassociation and 16S rRNA analysis in the present species definition. Int. J. Syst. Bacteriol. 44:846-849.

19. Tate, R. L., and J. C. Ensign. 1974. A new species of Arthrobacter which degrades picolinic acid. Can. J. Microbiol. 20:691-694.

20. Uchida, K., and K. Aida. 1977. Acyl type of bacterial cell wall: its simple identification by a colorimetric method. J. Gen. Microbiol. 23:249-260.

21. Wayne, L. G., D. J. Brenner, R. R. Colwell, P. A. D. Grimont, O. Kandler, M. Krichevsky, L. H. Moore, W. E. C. Moore, R. G. E. Murray, E. Stackebrandt, M. P. Starr, and H. G. Trüper. 1987. Report of the Ad Hoc Committee on Reconciliation of Approaches to Bacterial Systematics. Int. J. Syst. Bacteriol. 37:463-464. 